\title{
Effect of Reduced Rates of N, P and K on the Yield of Rice (Oryza sativa L.) and its Nutrient Uptake
}

\author{
ABM Masud Hasan ${ }^{1}$, Md. Mizanur Rahman ${ }^{2 *}$ and MA Hashem ${ }^{3}$ \\ ${ }^{l}$ Soil Resource Development Institute, Daulatpur, Khulna, Bangladesh \\ ${ }^{2}$ Department of Soil Science, Bangabandhu Sheikh Mujibur Rahman Agricultural University \\ Gazipur 1706, Bangladesh \\ ${ }^{3}$ Department of Soil Science, Bangladesh Agricultural University, Bangladesh \\ ${ }^{*}$ Corresponding author: E-mail: rmizanur@yahoo.com
}

\begin{abstract}
An experiment was conducted to study the yield response and nutrient uptake of rice (BRRI dhan30) to reduced rates of $\mathrm{N}, \mathrm{P}$ and $\mathrm{K}$ from the recommended fertilizer doses (RFD). The experiment was laid out in a randomized complete block design with four replicates. There were ten treatments viz. $\mathrm{T}_{1}$ (control), $\mathrm{T}_{2}(\mathrm{RFD}), \mathrm{T}_{3}(\mathrm{RFD}-20 \% \mathrm{~N}), \mathrm{T}_{4}(\mathrm{RFD}-40 \% \mathrm{~N}), \mathrm{T}_{5}(\mathrm{RFD}-20 \% \mathrm{P}), \mathrm{T}_{6}(\mathrm{FRD}-40 \% \mathrm{P}), \mathrm{T}_{7}$ $(\mathrm{RFD}-20 \% \mathrm{~K}), \mathrm{T}_{8}(\mathrm{RFD}-40 \% \mathrm{~K}), \mathrm{T}_{9}(\mathrm{RFD}-20 \% \mathrm{NPK})$ and $\mathrm{T}_{10}(\mathrm{RFD}-40 \% \mathrm{NPK})$. The recommended fertilizer doses of the crop were $100 \mathrm{~kg} \mathrm{~N}, 20 \mathrm{~kg} \mathrm{P}, 40 \mathrm{~kg} \mathrm{~K}, 20 \mathrm{~kg} \mathrm{~S}$ and $3 \mathrm{~kg} \mathrm{Zn} \mathrm{ha}{ }^{-1}$. The highest grain yield $\left(5.10 \mathrm{t} \mathrm{ha}^{-1}\right)$ and straw yield $\left(7.02 \mathrm{t} \mathrm{ha}^{-1}\right)$ were obtained by applying recommended doses of fertilizers which were insignificantly different from those observed in the treatments where N, P and K were reduced at the rate of $20 \%$ from the recommended doses. Similar results were also found in case of $\mathrm{P}, \mathrm{K}$ and $\mathrm{S}$ content and uptake by rice plant, while the variation for $\mathrm{N}$ was found significant. Overall results indicated that $20 \%$ reduction of either $\mathrm{N}$ or $\mathrm{P}$ or $\mathrm{K}$ from the recommended doses would not significantly affect the yield of rice.
\end{abstract}

Keywords: Reduced fertilization, rice, nutrient uptake

\section{Introduction}

Agriculture in Bangladesh is dominated by intensive rice cultivation. Globally, rice is the second most important cereal crop in terms of area but as food it is the most important since it provides more calorie than any other cereals. In Bangladesh, rice ranks first in terms of both area and production. Rice is not only the foremost staple food it also provides nearly $40 \%$ of total national employment and $48 \%$ of total rural employment (Bhuiyan and Karim, 1999). Soil is the principal source of plant nutrients. But nutrient supplying capacity of soils is gradually declining over time due to intensive cropping with high yielding rice varieties. Nitrogen, $\mathrm{P}$ and $\mathrm{K}$ are the primary nutrients and these deserve special attention because of their large requirement and positive influence on growth, yield and yield components of crops (Navin et al. 1996). However, these important elements have been found to be at imbalanced, excess and/or deficient levels in most agricultural soils of Bangladesh. Continuous and over application of chemical fertilizers accelerates the depletion of soil organic matter and degrades soil physical and chemical properties. Land degradation is a serious problem not only in Bangladesh but also in the world. Some $40 \%$ of the world's agricultural land is seriously degraded (Guardian, 2007). Among the worst affected regions, $75 \%$ of total land is unfertile in the Central America, one fifth of the total soil is degraded in Africa, and $11 \%$ is unsuitable for farming in Asia (Guardian, 2007). 
Excessive use of chemical fertilizers is a major factor for environmental pollution. Large scale use of chemical fertilizers has created a potential health hazard, has reduced microbial population and earthworm activities affecting soil health and has reduced utility of water bodies for men, animals and fishes (Smith et al., 1990). In addition, chemical fertilizers are always expensive inputs for crop production, especially in a developing country like Bangladesh. The reduced rates of $\mathrm{N}, \mathrm{P}$ and $\mathrm{K}$ not only maintain soil health for sustainable agriculture but also save part of the cost of crop production. Moreover, this will reduce agricultural runoff and leaching loss of nutrients, which in turn will reduce environmental pollution. Therefore, the present study was undertaken to investigate the effects of reduced rates of $\mathrm{N}, \mathrm{P}$ and $\mathrm{K}$ on yield and nutrient content of rice.

\section{Materials and Methods}

\subsection{Site description}

The experiment was conducted at the Research Farm of the Bangladesh Agricultural University during August to December, 2004. The farm is located at the latitude of $24.74^{\circ} \mathrm{N}$ and longitude $90.50^{\circ} \mathrm{E}$ and under the Agro-ecological Zone (AEZ) of Old Brahmaputra Floodplain. The experimental area belongs to sub-tropical climate and is characterized by high temperature accompanied by moderately high rainfall during April to September and low temperature during October to March.

The land was formed from old Brahmaputra river borne deposits which is moderately well drained, medium high and Non-calcareous Dark Grey Flood Plain with a silty loam texture and the reaction of the soil is slightly acidic. Organic matter and total $\mathrm{N}$ contents were 2.5 and $0.152 \%$, respectively. Available $\mathrm{P}$ and $\mathrm{S}$ were 14.17 and $13.76 \mathrm{mg} \mathrm{kg} \mathrm{kg}^{-1}$ respectively, whereas exchangeable $\mathrm{K}$ and $\mathrm{Ca}$ were 0.12 and 6.09 meq $100 \mathrm{~g}^{-1}$, respectively.

\subsection{Treatments and design}

The experiment was laid out in a randomized complete block design. There were 10 treatments including one control. The entire experimental area was divided into four blocks representing four replications and each block was sub-divided into 10 plots with raised bunds. The unit plot size was $4 \mathrm{~m} \times 3 \mathrm{~m}$; the plots were separated from each other by $0.5 \mathrm{~m}$ bunds (free space). There were $1.0 \mathrm{~m}$ drains between the blocks. The treatments were randomly distributed to subblocks in each block. The treatment combinations for the experiment were: $T_{1}$ (Control), $\mathrm{T}_{2}$ (Recommended Fertilizer Dose, RFD), $\mathrm{T}_{3}(\mathrm{RFD}-20 \% \mathrm{~N}), \mathrm{T}_{4}(\mathrm{RFD}-40 \% \mathrm{~N})$, $\mathrm{T}_{5}(\mathrm{RFD}-20 \% \mathrm{P}), \mathrm{T}_{6}(\mathrm{RFD}-40 \% \mathrm{P}), \mathrm{T}_{7}(\mathrm{RFD}$ $-20 \% \mathrm{~K}), \mathrm{T}_{8}(\mathrm{RFD}-40 \% \mathrm{~K}), \mathrm{T}_{9}(\mathrm{RFD}-20 \%$ NPK), and $\mathrm{T}_{10}$ (RFD - 40\% NPK). The recommended fertilizer doses of the test crop BRRI dhan30 were $100 \mathrm{~kg} \mathrm{~N}, 20 \mathrm{~kg} \mathrm{P}, 40 \mathrm{~kg} \mathrm{~K}$, $20 \mathrm{~kg} \mathrm{~S}$ and $3 \mathrm{~kg} \mathrm{Zn} \mathrm{ha}{ }^{-1}$ (BARC, 2007).

\subsection{Fertilizer application, transplanting and intercultural operations}

The full doses of $\mathrm{P}, \mathrm{K}, \mathrm{S}$ and $\mathrm{Zn}$ were applied using triple super phosphate (TSP), muriate of potash (MP), gypsum, and zinc sulphate, respectively at the time of final land preparation. Nitrogen as urea was applied in three equal splits: 10 days after transplanting, at maximum tillering stage and at booting stage of the crop. The 32 days old seedlings were transplanted in the plots on $12^{\text {th }}$ August 2003. Plant spacing was $20 \mathrm{~cm} \times 20 \mathrm{~cm}$. Intercultural operations such as weeding, pest control etc. were done as and when required. After transplanting 5-6 cm water was maintained in each plot throughout the growth period. There was no infestation of insect pests and diseases in the experimental crop.

\subsection{Harvesting and data collection}

The crop was harvested at full maturity on December 8, 2003. The harvested crop of each plot was bundled separately and grain yield, straw and biological yields were estimated. After harvesting of the crop, soil samples were collected from each plot at $0-15 \mathrm{~cm}$ depth and were analyzed for residual nutrients. 


\subsection{Chemical analysis of soil and plant samples}

The initial soil sample was collected before land preparation from $0-15 \mathrm{~cm}$ by means of an auger from 10 different locations covering the whole experimental plot and mixed thoroughly to make a composite sample. The composite sample was air dried, ground and sieved through a 20-mesh sieve and stored in a plastic bag for physical and chemical analysis.

Particle size analysis of soil was done by hydrometer method (Gee and Bauder, 1986). Soil $\mathrm{pH}$ was measured by glass electrode $\mathrm{pH}$ meter method using soil water ratio 1:2:5 (McLean, 1982). Organic matter content of soil samples were estimated by wet oxidation method (Nelson and Sommers, 1982). The total $\mathrm{N}$ of soil sample was determined following microKjeldahl method (Bremner and Mulvaney, 1982) Available soil phosphorus was measured by Olsen method (Olsen and Sommers, 1982) and available $\mathrm{S}$ was determined by turbidimetric method. Exchangeable $\mathrm{K}, \mathrm{Na}$ and $\mathrm{Ca}$ of soils were determined by flame photometer on the neutral ammonium acetate extract (Barker and Surh, 1982).

The collected grain and straw samples from each plot were dried in an oven at $65{ }^{\circ} \mathrm{C}$ for about 24 hours after which they were ground by a grinding mill. Later the ground samples were sieved through a 20-mesh sieve. The prepared samples were then chemically analyzed for $\mathrm{N}, \mathrm{P}$, $\mathrm{K}$ and $\mathrm{S}$ following diacid digestion procedure (Jones and Case, 1990; Watson and Issac, 1990).

The analysis of variance for various crop characters and also for various nutrients concentrations and nutrient uptake was done following the F-test. Mean comparisons of the treatments were made following the Duncan's Multiple Range Test (DMRT).

\section{Results and Discussion}

\subsection{Grain and straw yield}

The grain yields observed in the different treatments ranged from 3.81 to $5.10 \mathrm{t} \mathrm{ha}^{-1}$ and all the treatments showed higher grain yield over the control (Table 1). The highest grain yield of 5.10 $\mathrm{t} \mathrm{ha}^{-1}$ was achieved with the application of recommended doses of fertilizers, which was not significantly different from those observed in the treatments where $\mathrm{N}, \mathrm{P}$ and $\mathrm{K}$ doses were reduced by $20 \%$ singly. The grain yield obtained with the reduction of $20 \% \mathrm{~N}, \mathrm{P}$ and $\mathrm{K}$ were $4.88,4.93$ and $4.99 \mathrm{t} \mathrm{ha}^{-1}$, respectively. The findings of the recommended fertilizer doses in producing grain yields are in agreement with the findings of Singh et al. (1998) and Asaduzzaman et al. (1996). As the recommended fertilizers doses were calculated based on the soil inherent nutrients and crop demand, it is obvious that application of recommended doses of fertilizers will produce a good yield. However, the results revealed that the recommended fertilizer dose and the treatments where $20 \% \mathrm{~N}, \mathrm{P}$ and $\mathrm{K}$ were reduced from the recommended doses are equally efficient in producing grain yield but this will help to reduce the cost of production. Furthermore, application of fertilizers at reduced rates would help promote the eco-friendly environment.

Like grain yield, application of recommended fertilizers produced the highest amount of straw as well as biological yields, while the straw yield was statistically identical to those observed in the treatments where $\mathrm{N}, \mathrm{P}$ and $\mathrm{K}$ doses were reduced from the recommended doses at the rate of $20 \%$ singly (Table 1 ). The results revealed that application of recommended doses of fertilizers was more effective in producing the highest straw and biological yields. Straw yields were positively and significantly correlated with grain yield (Figure 1a). It is usual that application of adequate fertilizers produces more biomass of crops which is supported by many studies (Azim, 1999; Hoque, 1999). 
Table 1. Effect of reduced rates of N, P and $\mathrm{K}$ on the yield of rice

\begin{tabular}{|c|c|c|c|}
\hline Treatment & $\begin{array}{c}\text { Grain yield } \\
\left(\mathrm{t} \mathrm{ha}^{-1}\right)\end{array}$ & $\begin{array}{c}\text { Straw yield } \\
\left(\mathrm{t} \mathrm{ha}^{-1}\right)\end{array}$ & Biological yield ${ }^{* *}\left(\mathrm{t} \mathrm{ha}^{-1}\right)$ \\
\hline $\mathrm{T}_{1}$ (control) & $3.81 \mathrm{f}$ & $4.30 \mathrm{~g}$ & $8.11 \mathrm{~g}$ \\
\hline $\mathrm{T}_{2}\left(\mathrm{RFD}^{*}\right)$ & $5.10 \mathrm{a}$ & $7.02 \mathrm{a}$ & $12.12 \mathrm{a}$ \\
\hline $\mathrm{T}_{3}(\mathrm{RFD}-20 \% \mathrm{~N})$ & $4.88 \mathrm{ab}$ & $6.50 \mathrm{ab}$ & $11.38 \mathrm{bc}$ \\
\hline $\mathrm{T}_{4}(\mathrm{RFD}-40 \% \mathrm{~N})$ & $4.36 \mathrm{de}$ & $5.95 \mathrm{e}$ & $10.31 \mathrm{e}$ \\
\hline $\mathrm{T}_{5}(\mathrm{RFD}-20 \% \mathrm{P})$ & $4.93 \mathrm{a}$ & $6.86 \mathrm{ab}$ & $11.80 \mathrm{ab}$ \\
\hline $\mathrm{T}_{6}(\mathrm{RFD}-40 \% \mathrm{P})$ & $4.48 \mathrm{de}$ & $6.23 \mathrm{~d}$ & $10.70 \mathrm{de}$ \\
\hline $\mathrm{T}_{7}(\mathrm{RFD}-20 \% \mathrm{~K})$ & $4.99 \mathrm{a}$ & $6.95 \mathrm{a}$ & $11.94 \mathrm{ab}$ \\
\hline $\mathrm{T}_{8}(\mathrm{RFD}-40 \% \mathrm{~K})$ & $4.65 \mathrm{~cd}$ & $6.33 \mathrm{~cd}$ & $10.98 \mathrm{~cd}$ \\
\hline $\mathrm{T}_{9}$ (RFD-20\% NPK) & $4.74 \mathrm{bc}$ & $6.41 \mathrm{~b}$ & $11.15 \mathrm{~cd}$ \\
\hline $\mathrm{T}_{10}$ (RFD-40\%NPK) & $4.20 \mathrm{e}$ & $5.45 \mathrm{f}$ & $9.65 \mathrm{f}$ \\
\hline $\mathrm{SE}( \pm)$ & 0.148 & 0.115 & 0.266 \\
\hline
\end{tabular}

Figures in a column having common letters do not differ significantly at $5 \%$ level of significance

$*$ RFD $=$ Recommended Fertilizer Dose

** Biological yield $=$ grain + straw

Table 2. N, P, K and S content in grain and straw of BRRI dhan 30 as influenced by reduced rates of N, P and K

\begin{tabular}{|c|c|c|c|c|c|c|c|c|}
\hline \multirow[t]{2}{*}{ Treatment } & \multicolumn{2}{|c|}{$\% \mathrm{~N}$} & \multicolumn{2}{|c|}{$\% \mathrm{P}$} & \multicolumn{2}{|c|}{$\% \mathrm{~K}$} & \multicolumn{2}{|c|}{$\% \mathrm{~S}$} \\
\hline & Grain & Straw & Grain & Straw & Grain & Straw & Grain & Straw \\
\hline $\mathrm{T}_{1}$ (control) & $1.039 \mathrm{~d}$ & $0.372 \mathrm{~d}$ & $0.224 \mathrm{e}$ & $0.129 \mathrm{e}$ & $0.184 \mathrm{~d}$ & $1.302 \mathrm{~d}$ & $0.118 \mathrm{e}$ & $0.099 \mathrm{~d}$ \\
\hline $\mathrm{T}_{2}\left(\mathrm{RFD}^{*}\right)$ & $1.349 \mathrm{a}$ & $0.508 \mathrm{a}$ & $0.294 \mathrm{a}$ & $0.170 \mathrm{a}$ & $0.226 \mathrm{a}$ & $1.691 \mathrm{a}$ & $0.140 \mathrm{a}$ & $0.117 \mathrm{a}$ \\
\hline $\mathrm{T}_{3}(\mathrm{RFD}-20 \% \mathrm{~N})$ & $1.209 \mathrm{abc}$ & $0.460 \mathrm{a}$ & $0.288 \mathrm{ab}$ & $0.159 \mathrm{ab}$ & $0.222 \mathrm{a}$ & $1.624 \mathrm{a}$ & $0.136 \mathrm{ab}$ & $0.111 \mathrm{a}$ \\
\hline $\mathrm{T}_{4}(\mathrm{RFD}-40 \% \mathrm{~N})$ & $1.147 \mathrm{bcd}$ & $0.434 \mathrm{bc}$ & $0.273 \mathrm{~b}$ & $0.154 \mathrm{~b}$ & $0.204 \mathrm{c}$ & $1.543 \mathrm{ab}$ & $0.132 \mathrm{~cd}$ & $0.109 \mathrm{~b}$ \\
\hline $\mathrm{T}_{5}(\mathrm{RFD}-20 \% \mathrm{P})$ & $1.219 \mathrm{abc}$ & $0.465 \mathrm{a}$ & $0.286 \mathrm{ab}$ & $0.158 \mathrm{ab}$ & $0.228 \mathrm{a}$ & $1.631 \mathrm{a}$ & $0.137 \mathrm{ab}$ & $0.112 \mathrm{a}$ \\
\hline $\mathrm{T}_{6}(\mathrm{RFD}-40 \% \mathrm{P})$ & $1.178 \mathrm{bcd}$ & $0.450 \mathrm{~b}$ & $0.248 \mathrm{~d}$ & $0.148 \mathrm{c}$ & $0.210 \mathrm{~b}$ & $1.536 \mathrm{abc}$ & $0.133 \mathrm{c}$ & $0.110 \mathrm{~b}$ \\
\hline $\mathrm{T}_{7}(\mathrm{RFD}-20 \% \mathrm{~K})$ & $1.256 \mathrm{ab}$ & $0.467 \mathrm{a}$ & $0.287 \mathrm{ab}$ & $0.163 \mathrm{ab}$ & $0.221 \mathrm{a}$ & $1.553 \mathrm{ab}$ & $0.138 \mathrm{ab}$ & $0.113 \mathrm{a}$ \\
\hline $\mathrm{T}_{8}(\mathrm{RFD}-40 \% \mathrm{~K})$ & $1.194 \mathrm{bc}$ & $0.451 \mathrm{~b}$ & $0.273 \mathrm{c}$ & $0.155 \mathrm{~b}$ & $0.200 \mathrm{c}$ & $1.497 \mathrm{bc}$ & $0.135 \mathrm{abc}$ & $0.109 \mathrm{~b}$ \\
\hline $\mathrm{T}_{9}(\mathrm{RFD}-20 \% \mathrm{NPK})$ & $1.201 \mathrm{abc}$ & $0.452 \mathrm{~b}$ & $0.280 \mathrm{ab}$ & $0.156 \mathrm{~b}$ & $0.217 \mathrm{~b}$ & $1.551 \mathrm{ab}$ & $0.134 \mathrm{c}$ & $0.110 \mathrm{~b}$ \\
\hline $\mathrm{T}_{10}(\mathrm{RFD}-40 \% \mathrm{NPK})$ & $1.101 \mathrm{~cd}$ & $0.403 \mathrm{c}$ & $0.245 \mathrm{~d}$ & $0.139 \mathrm{~d}$ & $0.192 \mathrm{~cd}$ & $1.418 \mathrm{~cd}$ & $0.125 \mathrm{~d}$ & $0.103 \mathrm{~cd}$ \\
\hline $\mathrm{SE}( \pm)$ & 0.063 & 0.023 & 0.0025 & 0.0026 & 0.0234 & 0.054 & 0.0024 & 0.0019 \\
\hline
\end{tabular}

Figure (s) in a column having common letter(s) do not differ significantly at $5 \%$ level of significance

$*$ RFD = Recommended Fertilizer Dose 


\subsection{Nutrient contents in grain and straw}

\subsubsection{Nitrogen content}

There was significant effect of the different treatments on $\mathrm{N}$ concentration of both rice grain and straw (Table 2). The $\mathrm{N}$ content in grain varied from 1.04 to $1.35 \%$, and the maximum $\mathrm{N}$ content in grain was observed with the application of recommended fertilizers which was statistically similar to those recorded in the treatments where NPK were reduced from the recommended doses at the rates of $20 \%$ singly and altogether, respectively. The lowest concentration of $\mathrm{N}$ was recorded in the control treatment which was statistically similar to those observed in the treatments.

The concentration of $\mathrm{N}$ in straw due to different treatments ranged from 0.37 to $0.51 \%$, where the highest concentration was found in the treatment of recommended fertilizers (Table 2). The difference in $\mathrm{N}$ concentrations in straw among the treatments of recommended fertilizers and the treatments where $\mathrm{N}, \mathrm{P}$ and $\mathrm{K}$ were reduced at the rate of $20 \%$ singly were insignificant. The grain $\mathrm{N}$ contents were always higher in all the treatments than that of straw. Phongpan et al. (1988), Azim (1999) and Hoque (1999) also reported similar results.

Nitrogen uptake by grain and straw varied from 39.53 to $68.79 \mathrm{~kg} \mathrm{ha}^{-1}$ and 16.04 to $35.66 \mathrm{~kg} \mathrm{ha}^{-1}$, respectively. The highest amounts of $\mathrm{N}$ uptake by grain, straw and grain plus straw were recorded in the plots where chemical fertilizers were applied as per recommendation (Table 3). A linear relationship between grain yield and total $\mathrm{N}$ uptake was obtained (Figure 1b). Phongpan et al. (1988) reported that $\mathrm{N}$ uptake by rice increased significantly with increasing rates of urea application. Similar results were also noted by Kadu et al. (1991).

\subsubsection{Phosphorus content}

Phosphorus content in grain ranged from 0.22 to $0.29 \%$, while in the straw it varied from 0.13 to $0.17 \%$ and $\mathrm{P}$ concentration in grain was higher than that in straw in all the treatments (Table 2). The concentrations of $\mathrm{P}$ both in the grain and straw were insignificantly different among the treatments of recommended fertilizers and individual reduction of $\mathrm{N}, \mathrm{P}$ and $\mathrm{K}$ at the rate of $20 \%$. The difference of grain $\mathrm{P}$ was not significant among the above said treatments and the treatment where $20 \%$ NPK altogether was reduced. It was observed that P content in both grain and straw of rice was the highest with the increasing N, P and K rates (Hoque, 1999; Azim, 1999).

The ranges of $\mathrm{P}$ uptake observed in grain and straw were 8.49 to $14.99 \mathrm{~kg} \mathrm{ha}^{-1}$ and 5.54 to $11.93 \mathrm{~kg} \mathrm{ha}^{-1}$, respectively (Table 3 ). The $\mathrm{P}$ uptake by grain in the treatment of recommended fertilizers was statistically identical to those noted in the treatments of $20 \%$ reduction of N, P and $\mathrm{K}$ singly. But the straw $\mathrm{P}$ was significantly higher over all other treatments. A significant linear relationship between total $\mathrm{P}$ uptake and grain yield was observed (Figure 2a). Datta and Gupta (1984) and Subbian et al. (1989) stated that total P uptake increased with the increased levels of $\mathrm{P}$.

\subsubsection{Potassium content}

Potassium content in grain varied from 0.18 to $0.23 \%$, while in straw it was 1.30 to $1.69 \%$ (Table 3). The differences of $\mathrm{K}$ concentration in grain among the treatments of recommended fertilizers and $20 \%$ reduction of $\mathrm{N}, \mathrm{P}$ and $\mathrm{K}$ singly were insignificant. However, the differences of $\mathrm{K}$ concentration in straw among the above treatments and the treatments of $40 \%$ reduction of $\mathrm{N}$ and $\mathrm{P}$ singly and $20 \%$ reduction of NPK altogether were insignificant. Hoque (1999) showed that K concentration in both grain and straw of rice was the highest with N, P and $\mathrm{K}$ application which is in aggrement with our findings.

The $\mathrm{K}$ uptake by grain and straw varied from 7.02 to $11.52 \mathrm{~kg} \mathrm{ha}^{-1}$ and 56.00 to $118.71 \mathrm{~kg} \mathrm{ha}^{-1}$, respectively (Table 4). The $\mathrm{K}$ uptake in the treatment of recommended fertilizers was insignificantly different to those observed in the treatments of $20 \%$ reduction of $\mathrm{N}, \mathrm{P}$ and $\mathrm{K}$ singly and NPK altogether. 

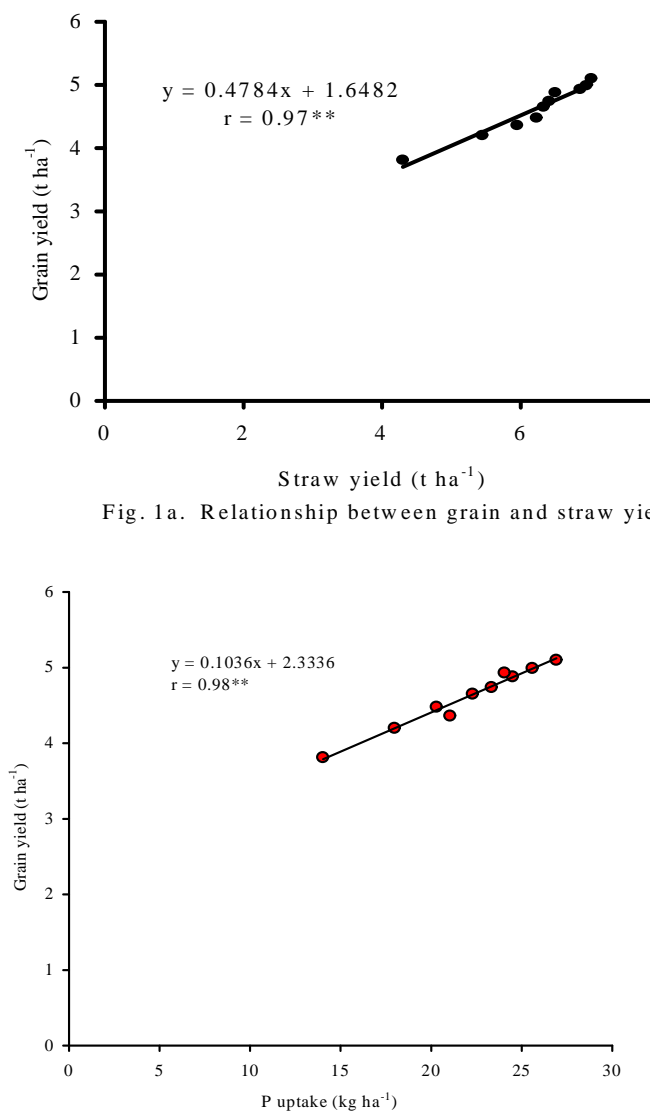

Fig. 2a. Relationship between $P$ uptake and grain yield

It was observed that $\mathrm{K}$ concentration and uptake was higher in rice straw than in grain in all the treatments. As K concentration, economic yields and biomass were higher in the treatment of recommended fertilizers, total $\mathrm{K}$ uptake was the highest in this treatment which was significantly different from all other treatments. A linear relationship between grain yield and $\mathrm{K}$ uptake was obtained (Figure 2b).

\subsubsection{Sulphur content}

The maximum $\mathrm{S}$ content in grain and straw were 0.14 and $0.12 \%$, respectively in the treatment of recommended fertilizers, which were insignificantly different with the treatments of $20 \%$ reduction of $\mathrm{N}, \mathrm{P}$ and $\mathrm{K}$ singly (Table 3 ). Similar to $\mathrm{S}$ concentration, its uptake by grain,

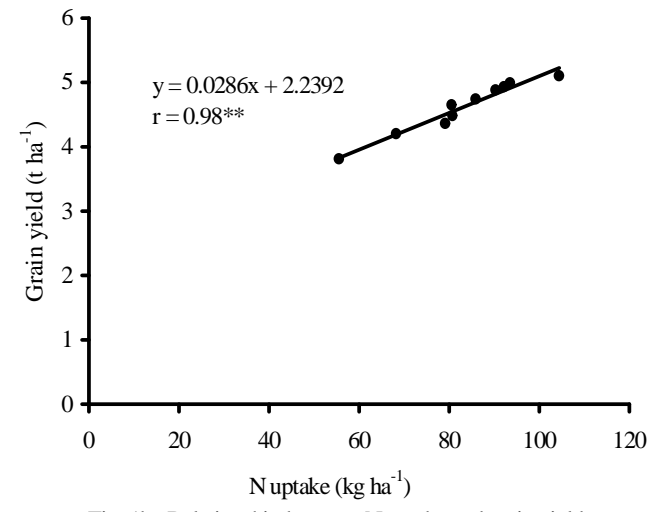

Fig. 1b. Relationship between $\mathrm{N}$ uptake and grain yield

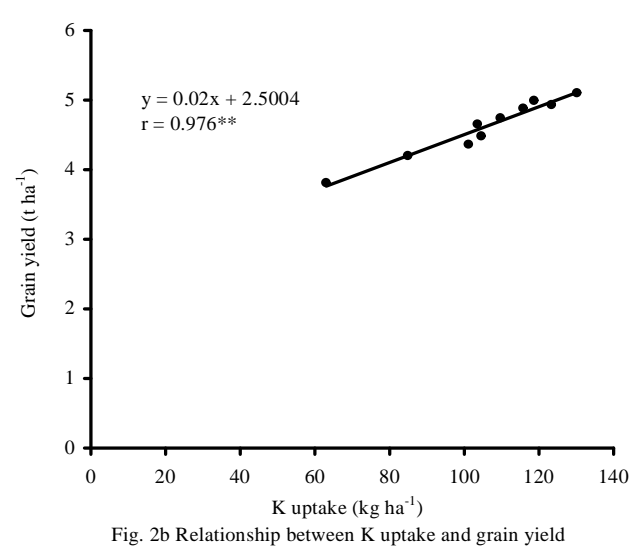

straw and grain plus straw was also higher in the treatment of recommended fertilizers (Table 4). Islam et al. (1990) stated that application of S combined with other nutrients increased the concentration of $\mathrm{S}$ in both grain and straw. Similar results were also found by Poongothai et al. (1999) and Sakal (1995).

\subsection{Post- harvest soil properties}

The $\mathrm{pH}$ and $\mathrm{OM}$ content of the post-harvest soils were not significantly influenced by treatments (Table 5). The $\mathrm{pH}$ of the post-harvest soils ranged from 6.4 to 6.7 . The $\mathrm{pH}$ value of initial soil was 6.7. A decrease in $\mathrm{pH}$ value of the postharvest soils might be due to acidic effect of $\mathrm{N}$, $\mathrm{P}, \mathrm{K}, \mathrm{S}$ and $\mathrm{Zn}$ supplied from respective fertilizers. 
Table 3. Effect of reduced rates of $\mathrm{N}, \mathrm{P}$ and $\mathrm{K}$ on $\mathrm{N}$ and $\mathrm{P}$ uptake by BRRI dhan 30

\begin{tabular}{|c|c|c|c|c|c|c|}
\hline \multirow[t]{2}{*}{ Treatment } & \multicolumn{3}{|c|}{$\mathrm{N}$ uptake $\left(\mathrm{kg} \mathrm{ha}^{-1}\right)$} & \multicolumn{3}{|c|}{ P uptake $\left(\mathrm{kg} \mathrm{ha}^{-1}\right)$} \\
\hline & Grain & Straw & Total & Grain & Straw & Total \\
\hline $\mathrm{T}_{1}$ (control) & $39.53 \mathrm{e}$ & $16.04 \mathrm{~g}$ & $55.58 \mathrm{f}$ & $8.49 \mathrm{f}$ & $5.54 \mathrm{i}$ & $14.03 \mathrm{~h}$ \\
\hline $\mathrm{T}_{2}(\mathrm{RFD} *)$ & $68.79 \mathrm{a}$ & $35.66 \mathrm{a}$ & $104.41 \mathrm{a}$ & $14.99 \mathrm{a}$ & $11.93 \mathrm{a}$ & $26.92 \mathrm{a}$ \\
\hline $\mathrm{T}_{3}(\mathrm{RFD}-20 \% \mathrm{~N})$ & $60.22 \mathrm{~b}$ & $29.90 \mathrm{bcd}$ & $90.36 \mathrm{bc}$ & $14.03 \mathrm{ab}$ & $10.48 \mathrm{~cd}$ & $24.51 \mathrm{c}$ \\
\hline $\mathrm{T}_{4}(\mathrm{RFD}-40 \% \mathrm{~N})$ & $52.13 \mathrm{~cd}$ & $25.84 \mathrm{e}$ & $79.17 \mathrm{~d}$ & $11.91 \mathrm{~cd}$ & $9.13 \mathrm{~g}$ & $21.05 \mathrm{f}$ \\
\hline $\mathrm{T}_{5}(\mathrm{RFD}-20 \% \mathrm{P})$ & $60.29 \mathrm{~b}$ & $31.93 \mathrm{bc}$ & $92.15 \mathrm{bc}$ & $14.10 \mathrm{ab}$ & $10.84 \mathrm{bc}$ & $24.94 \mathrm{bc}$ \\
\hline $\mathrm{T}_{6}(\mathrm{RFD}-40 \% \mathrm{P})$ & $53.33 \mathrm{c}$ & $28.03 \mathrm{de}$ & $80.74 \mathrm{~d}$ & $11.09 \mathrm{de}$ & $9.21 \mathrm{~g}$ & $20.30 \mathrm{f}$ \\
\hline $\mathrm{T}_{7}(\mathrm{RFD}-20 \% \mathrm{~K})$ & $61.22 \mathrm{~b}$ & $32.30 \mathrm{ab}$ & $93.53 \mathrm{~b}$ & $14.29 \mathrm{ab}$ & $11.30 \mathrm{~b}$ & $25.59 \mathrm{~b}$ \\
\hline $\mathrm{T}_{8}(\mathrm{RFD}-40 \% \mathrm{~K})$ & $52.72 \mathrm{c}$ & 28.41 cde & $80.55 \mathrm{~d}$ & $12.48 \mathrm{c}$ & 9.82 ef & $22.29 \mathrm{e}$ \\
\hline $\mathrm{T}_{9}(\mathrm{RFD}-20 \% \mathrm{NPK})$ & $56.93 \mathrm{bc}$ & 28.97 be & $85.90 \mathrm{~cd}$ & $13.27 \mathrm{bc}$ & $10.06 \mathrm{de}$ & $23.33 \mathrm{~d}$ \\
\hline $\mathrm{T}_{10}(\mathrm{RFD}-40 \% \mathrm{NPK})$ & $46.20 \mathrm{~d}$ & $22.03 \mathrm{f}$ & $68.23 \mathrm{e}$ & $10.27 \mathrm{e}$ & $7.71 \mathrm{~h}$ & $17.98 \mathrm{~g}$ \\
\hline $\mathrm{SE}( \pm)$ & 2.93 & 1.68 & 3.44 & 0.635 & 0.275 & 0.492 \\
\hline
\end{tabular}

Figure (s) in a column having common letter(s) do not differ significantly at $5 \%$ level of significance

$*$ RFD $=$ Recommended Fertilizer Dose

Table 4. Effect of reduced rates of N, P and K on K and S uptake by BRRI dhan30

\begin{tabular}{|c|c|c|c|c|c|c|}
\hline \multirow[t]{2}{*}{ Treatment } & \multicolumn{3}{|c|}{ K uptake $\left(\mathrm{kg} \mathrm{ha}^{-1}\right)$} & \multicolumn{3}{|c|}{ S uptake $\left(\mathrm{kg} \mathrm{ha}^{-1}\right)$} \\
\hline & Grain & Straw & Total & Grain & Straw & Total \\
\hline $\mathrm{T}_{1}$ (control) & $7.02 \mathrm{e}$ & $56.00 \mathrm{f}$ & $63.02 \mathrm{~h}$ & $4.49 \mathrm{e}$ & $4.24 \mathrm{f}$ & $8.73 \mathrm{~h}$ \\
\hline $\mathrm{T}_{2}\left(\mathrm{RFD}^{*}\right)$ & $11.52 \mathrm{a}$ & $118.71 \mathrm{a}$ & $130.23 \mathrm{a}$ & $7.14 \mathrm{a}$ & $8.21 \mathrm{a}$ & $15.35 \mathrm{a}$ \\
\hline $\mathrm{T}_{3}(\mathrm{RFD}-20 \% \mathrm{~N})$ & $10.80 \mathrm{ab}$ & $105.00 \mathrm{bc}$ & $115.80 \mathrm{~cd}$ & $6.62 \mathrm{ab}$ & $7.23 \mathrm{c}$ & $13.84 \mathrm{~cd}$ \\
\hline $\mathrm{T}_{4}(\mathrm{RFD}-40 \% \mathrm{~N})$ & $8.88 \mathrm{~cd}$ & $91.93 \mathrm{~d}$ & $101.20 \mathrm{f}$ & $5.77 \mathrm{~cd}$ & $6.47 \mathrm{~d}$ & $12.31 \mathrm{f}$ \\
\hline $\mathrm{T}_{5}(\mathrm{RFD}-20 \% \mathrm{P})$ & $11.23 \mathrm{a}$ & $111.90 \mathrm{ab}$ & $123.40 \mathrm{~b}$ & $6.75 \mathrm{ab}$ & $7.72 \mathrm{~b}$ & $14.22 \mathrm{bc}$ \\
\hline $\mathrm{T}_{6}(\mathrm{RFD}-40 \% \mathrm{P})$ & $9.43 \mathrm{bc}$ & $95.16 \mathrm{~d}$ & $104.60 \mathrm{ef}$ & $5.92 \mathrm{bcd}$ & $6.85 \mathrm{c}$ & $12.77 \mathrm{ef}$ \\
\hline $\mathrm{T}_{7}(\mathrm{RFD}-20 \% \mathrm{~K})$ & $11.03 \mathrm{a}$ & $107.80 \mathrm{bc}$ & $118.74 \mathrm{bc}$ & $6.87 \mathrm{a}$ & $7.85 \mathrm{ab}$ & $14.72 \mathrm{ab}$ \\
\hline $\mathrm{T}_{8}(\mathrm{RFD}-40 \% \mathrm{~K})$ & $9.51 \mathrm{bc}$ & $94.04 \mathrm{~d}$ & $103.60 \mathrm{ef}$ & $6.29 \mathrm{abc}$ & $6.89 \mathrm{c}$ & $13.19 \mathrm{de}$ \\
\hline $\mathrm{T}_{9}(\mathrm{RFD}-20 \% \mathrm{NPK})$ & $10.29 \mathrm{abc}$ & $99.42 \mathrm{~cd}$ & $109.71 \mathrm{de}$ & $6.36 \mathrm{abc}$ & $7.05 \mathrm{c}$ & $13.41 \mathrm{cde}$ \\
\hline $\mathrm{T}_{10}$ (RFD-40\% NPK) & $8.06 \mathrm{de}$ & $76.87 \mathrm{e}$ & $84.93 \mathrm{~g}$ & $5.24 \mathrm{de}$ & $5.64 \mathrm{e}$ & $10.88 \mathrm{~g}$ \\
\hline $\mathrm{SE}( \pm)$ & 0.638 & 4.11 & 3.14 & 0.368 & 0.184 & 0.388 \\
\hline
\end{tabular}

Figure (s) in a column having common letter(s) do not differ significantly at $5 \%$ level of significance

* RFD $=$ Recommended Fertilizer Dose 
Table 5. Effect of reduced rates of N, $\mathrm{P}$ and $\mathrm{K}$ on residual soil nutrients

\begin{tabular}{|c|c|c|c|c|c|c|}
\hline Treatment & $\mathrm{pH}$ & $\begin{array}{l}\text { Organic matter } \\
\qquad(\%)\end{array}$ & Total N $(\%)$ & $\begin{array}{c}\text { Available } P \\
\left(\mathrm{mg} \mathrm{kg}^{-1}\right)\end{array}$ & $\begin{array}{l}\text { Exchangeable } \mathrm{K} \\
\text { (meq } 100 \mathrm{~g}^{-1} \text { soil) }\end{array}$ & $\begin{array}{l}\text { Available } S \\
\left(\mathrm{mg} \mathrm{kg}^{-1}\right)\end{array}$ \\
\hline $\mathrm{T}_{1}$ (control) & 6.68 & 2.39 & $0.149 a$ & $11.00 \mathrm{e}$ & $0.103 c$ & $10.91 \mathrm{e}$ \\
\hline $\mathrm{T}_{2}\left(\mathrm{RFD}^{*}\right)$ & 6.41 & 2.13 & $0.135 c$ & $15.02 \mathrm{a}$ & $0.128 a$ & $15.06 \mathrm{a}$ \\
\hline $\mathrm{T}_{3}(\mathrm{RFD}-20 \% \mathrm{~N})$ & 6.47 & 2.25 & $0.141 \mathrm{~b}$ & $14.74 \mathrm{ab}$ & $0.123 a$ & $14.51 \mathrm{ab}$ \\
\hline $\mathrm{T}_{4}(\mathrm{RFD}-40 \% \mathrm{~N})$ & 6.52 & 2.27 & $0.143 b$ & $13.88 b c$ & $0.118 b$ & $13.93 b$ \\
\hline $\mathrm{T}_{5}(\mathrm{RFD}-20 \% \mathrm{P})$ & 6.54 & 2.22 & $0.136 c$ & $14.22 \mathrm{ab}$ & $0.124 a$ & $14.33 \mathrm{ab}$ \\
\hline $\mathrm{T}_{6}(\mathrm{RFD}-40 \% \mathrm{P})$ & 6.56 & 2.24 & $0.140 b c$ & $12.90 \mathrm{~d}$ & $0.116 b$ & $13.23 \mathrm{c}$ \\
\hline $\mathrm{T}_{7}(\mathrm{RFD}-20 \% \mathrm{~K})$ & 6.51 & 2.23 & $0.139 b c$ & $14.27 \mathrm{ab}$ & $0.122 \mathrm{a}$ & $14.35 \mathrm{ab}$ \\
\hline $\mathrm{T}_{8}(\mathrm{RFD}-40 \% \mathrm{~K})$ & 6.57 & 2.26 & $0.141 \mathrm{~b}$ & $13.92 b c$ & $0.115 b$ & $13.44 c$ \\
\hline $\mathrm{T}_{9}(\mathrm{RFD}-20 \% \mathrm{NPK})$ & 6.58 & 2.28 & $0.142 b$ & $13.99 b c$ & $0.119 b$ & $14.25 \mathrm{ab}$ \\
\hline $\mathrm{T}_{10}(\mathrm{RFD}-40 \% \mathrm{NPK})$ & 6.59 & 2.29 & $0.144 a b$ & $12.37 \mathrm{~d}$ & $0.106 c$ & $12.21 \mathrm{~d}$ \\
\hline Initial soil & 6.71 & 2.50 & 0.152 & 14.17 & 0.115 & 13.76 \\
\hline $\mathrm{SE}( \pm)$ & NS & NS & 0.0023 & 0.396 & 0.0027 & 0.414 \\
\hline \multicolumn{7}{|c|}{$\begin{array}{l}\text { Figure (s) in a column having common letter }(s) \text { do not differ significantly at } 5 \% \text { level of significance } \\
* \mathrm{RFD}=\text { Recommended Fertilizer Dose }\end{array}$} \\
\hline
\end{tabular}


Swarup and Singh (1994) reported that application of fertilizers decreased the soil $\mathrm{pH}$. The $\mathrm{OM}$ content of the post- harvest soils varied from 2.13 to $2.39 \%$ and it tended to decrease in the soils treated with more fertilizers. This could be because application of chemical fertilizers accelerates the decomposition of organic materials in soil. Moreover, in the tropical climate soil microorganisms are more active in the decomposition of soil organic matter. Similar results were also reported by Razzaque (1996) and Azim (1999).

Residual soil N, P, K and $\mathrm{S}$ were significantly influenced by different treatments (Table 5). Soil treated with more chemical fertilizers showed a slight decrease in the total $\mathrm{N}$ content of post harvest soils. The highest total $\mathrm{N}$ content $(0.149 \%)$ was obtained in the control treatment while the lowest $(0.135 \% \mathrm{~N})$ was in the treatment of recommended fertilizers. The results revealed that rice cultivation with chemical fertilizers had a decreasing effect on the total $\mathrm{N}$ content of the post-harvest soils. Rabikowsha et al. (1993) reported that addition of NPK fertilizers decreased the total $\mathrm{N}$ content of soil. The highest amount of residual $\mathrm{P}, \mathrm{K}$ and $\mathrm{S}$ were recorded in the treatment where recommended doses of fertilizers were applied, which was statistically identical to those noted in the treatments of $20 \%$ reduction of $\mathrm{N}, \mathrm{P}$ and $\mathrm{K}$ singly from the recommended doses of fertilizers. The lowest amount of residual $\mathrm{P}$ was observed in the control treatment. It was observed that soils treated with increasing rate of phosphatic fertilizer gave higher values of residual phosphorus. Bhuiyan and Saha (1992) found that available soil $\mathrm{P}$ content increased substantially due to application of $\mathrm{P}$ fertilizer in each crop.

\section{Conclusions}

Maximum grain and straw yields of rice were obtained in the treatment where recommended fertilizers were applied but these yields did not vary significantly with the yield observed in the treatments with the reduction of either $\mathrm{N}$ or $\mathrm{P}$ or $\mathrm{K}$ at the rate $20 \%$ from the recommended doses. Application of fertilizers at reduced rates obviously helps promote the eco-friendly environment via reducing and limiting the sources and amount of environmental pollution from agricultural runoff and leaching. Ample supply of nutrients using organic sources with the supplementation of inorganic fertilizers would help maintain soil health and sustain its productive capacity and thus ensure a sustainable environment.

\section{References}

Asaduzzaman, M., Hashem, M. A. Islam, M. R. and Jahiruddin, M. 1996. Contribution of indigenous blue green to rice yield in relation to different added nutrients. Thai Journal of Agricultural Science, 29(2):157-164.

Azim, S. M. A. 1999. Effect of sulphur, zinc and boron supplied from manures and fertilizers on BRRI Dhan 29. M.S. Thesis, Dept. Soil Science (January-June, 1999), BAU, Mymensingh.

Barker, D. E. and Suhr, N. H. 1982. Atomic absorption and flame emission spectroscopy. In: Methods of soil analysis, Part 2, Chemical and microbiological properties, (eds.) A. L. Page, R. H. Miller and D. R. Keeney, American Society of Agronomy Inc., Madison, WI, USA, 13-26 pp.

Bhuiya, Z. H., Islam, A. K. M. N. and Hoque, M. S. 1979. Yield and protein content of IR8 rice on influence by N, P and K fertilizer. Bangladesh Journal of Agricultural Science, 6(2):127-130.

Bhuiyan, N. I. and Saha, P. K. 1992. Effect of frequency of $\mathrm{P}$ fertilization on the growth, yield and $\mathrm{P}$ nutrient of wetland rice and $\mathrm{P}$ fertility of soil. Inter-Congress Conf. IV. December 1-3. Dhaka, Bangladesh. 10 p.

Bhuyian, S. I. and Karim. A. N. M. R. 1999. Rice production in Bangladesh: an overview. In: Increasing rice production in BangladeshChallenges and Strategies. IRRI. BRRI. 1-11 pp.

Bremner, J. M. and Mulvaney, C. S. 1982. Total nitrogen. In: Methods of soil analysis, Part 2, Chemical and microbiological properties, (eds.) A. L. Page, R. H. Miller and D. R. Keeney, American Society of Agronomy and Soil Science Society of America, Inc., Madison, Wisconsin, USA, 595-624 pp.

Datta, M. and Gupta, R. K. 1984. Effect of superphosphate on the yield of rice and wheat on acid soil of Nagaland. Journal of Indian Society of Soil Science, 32(2):299-302.

Gee, G. W. and Bauder, J. W. 1986. Particle size analysis. In: Methods of soil analysis, Part 1, Physical and mineralogical methods, (ed.) K. 
Arnold, American Society of Agronomy Inc., Madison, WI, USA, 383-411 pp.

Guardian, 2007. Gurdian News and Media Corporation. URL:www.gurdian.co.uk

Hoque, M. A. 1999. Response of BRRI Dhan29 to $\mathrm{S}, \mathrm{Zn}$ and $\mathrm{B}$ supplied from manures and fertilizers. M.S. Thesis, Dept. Soil Science (January-June, 1999), BAU, Mymensingh.

Hossain, A., Islam, M. R. and Miah, N. A. 1980. Response of rice to sulphur and zinc fertilization. Bangladesh Journal of Agricultural Science, 14(2):131-134.

Idris, M. and Matin, M. A. 1990. Response of four exotic strains of aman rice to urea. Bangladesh Journal of Agricultural Science, 17(2):271-275.

Islam, M. R., Hoqe, M. S. and Bhuiya, Z. H. 1990. Effect of nitrogen \& sulpur on yield response and nitrogen \& sulphur composition of rice. Bangladesh Journal of Agricultural Science, 17(2):299-302.

Jones, Jr. J. B. and Case, V. W. 1990. Sampling, handling and analyzing plant tissue samples. In: Soil testing and plant analysis, $3^{\text {rd }}$ edition, SSSA Book series 3, (ed.) W. S. Westermaan, Soil Science Society of America, Madison, WI, USA, 389-427 pp.

McLean, E. O. 1982. Soil $\mathrm{pH}$ and lime requirement. In: Methods of soil analysis, Part 2, Chemical and microbiological properties, (eds.) A. L. Page, R. H. Miller and D. R. Keeney, American Society of Agronomy Inc., Madison, WI, USA, 199-224 pp.

Navin, K., Singh, V. K., Thakur, R. B. and Kumar, N. 1996. Effect of level and time of $\mathrm{N}$ application on the performance of winter rice. Journal of Applied BIology, 6(1-2):48-53.

Nelson, D. W. and Sommers, L. E. 1982. Total carbon, organic carbon, and organic matter In: Methods of soil analysis, Part 2, Chemical and microbiological properties, (eds.) A. L. Page, R. H. Miller and D. R. Keeney (eds.), American Society of Agronomy Inc., Madison, WI, USA, 539-579 pp.

Olsen, S. R. and Sommers, L. E. 1982. Phosphorus. In: Methods of soil analysis, Part 2, Chemical and microbiological properties, (eds.) A. L. Page, R. H. Miller and D. R. Keeney,
American Society of Agronomy Inc., Madison, WI, USA, 403-430 pp.

Phongpan, S., Vacharotayan, S. and Kunazawa, K. 1988. Rate and efficiency of urea fertilizer in wetland soil. Soil Science and Plant Nutrition, 34(1):117-126.

Poongothai, S., Savithri, R. K. and Joseph, B. 1999. Influence of gypsum and green leaf manure application on rice and soil deficiency in sulphur. Journal of Indian Society of Soil, 47(1):96-99.

Rabikowsha, B., Wilk, K. and Piszez, U. 1993. Effect of 20 years different mineral fertilization on some properties of loamy soil. Hugona Kollataja W. Krakuwie, Sesja Naukow. 37:119-131.

Razzaque, M. M. A. 1996. comparative study on the effect of rice-cut-straw, farmyard manure and fertilizer $\mathrm{N}$ on the growth and yield of BR11 rice. MS Thesis, Dept. Soil Science (Jan.-June, 1999), BAU, Mymensingh.

Sakal, R. 1995. Soil sulphur deficiency and crop responses to sulphur in Bihar, India. Sulphur in Agriculture. Sulphur Institute, Washington D.C. 19:28.

Singh, S. P., Devi, B. S. and Subbiah, S. V. 1998. Effect on $\mathrm{N}$ levels and lime of application of grain of hybrid rice. International Rice Research. Notes, 23(1):25.

Smith, S. J., Schepers, J. S. and Porter, L. R. 1990. Assessing and managing an agriculture nitrogen losses to the environment. Advances in Soil Science, 14:1-4.

Subbian, P., Raja, S. K. and Palaniappan, S. P. 1989. Effect of levels and sources of phosphorus on yield and nutrient uptake of rice. Journal of the Indian Society of Soil Science, 26(3): 312-314.

Swarup, A. and Singh, K.N. 1994. Effect of gypsum, farmyard manure and nitrogen on ameliorating highly sodic soil and yields of rice and wheat. International Rice Research Notes (Philippines). 9(3):22-23.

Watson, M. E. and Isaac, R. A. 1990. Analytical instruments for soil and plant analysis. In: Soil testing and plant analysis, $3^{\text {rd }}$ edition. SSSA Book series 3, (ed.) W.L. Westermaan, Soil Science Society of America, Madison, WI, USA, 691-740 pp 
